\title{
TEORI ADAT DALAM QOWAID FIQHIYAH DAN PENERAPANYA DALAM HUKUM KELUARGA ISLAM
}

\author{
Heri Mahfudhi' ${ }^{1}$ M. Kholis Arrosid ${ }^{2}$ \\ ${ }^{1}$ Dosen IAIN Salatiga \\ Email:mahfudhi@iainsalatiga.ac.id \\ ${ }^{2}$ Dosen UII Yogyakarta \\ Email: colisaros@gmail.com
}

\begin{abstract}
One of the five major fiqhiyah rules that has a broad scope of discussion branches is Al-'adah muhakkamah. This rule is built on the basis of adat and local wisdom that exists in every community, where this custom is continuously carried out by the community without any denial of them. In fact, individuals who violate these customs will be considered as foreigners. Therefore, Islam makes the customs of the community as a legal basis as long as it fulfills the requirements set by the Shari'a. This paper aims to examine the rules of fiqhiyah "al-'âdat muhakkamah" in general and its implementation in the field of the Islamic family. This type of research is qualitative which relies on the analysis of data obtained from classical and contemporary literature. The results of the study suggest that al-'adah is something that occurs repeatedly which is accepted by common sense and human nature. The theory can also be a judge or legal determinant as long as it does not conflict with the Shari'a or does not go out of the way of maqosid sharia. The rule of al-'Adah muhakkamah can also be implemented as a judge in the field of Islamic family law both classical and contemporary.
\end{abstract}

Keyword: Al-'adah Muhakkamah, Customary Theory, Fiqhiyah Rules, Islamic Family Law

\begin{abstract}
Abstrak
Salah satu dari lima kaidah fiqhiyah besar yang memiliki cakupan cabang pembahasan yang luas adalah Al-'adah muhakkamah. Kaidah ini dibangun atas landasan adat dan kearifan lokal yang ada pada setiap komunitas masyarakat, dimana adat ini secara kontinu dilakukan oleh masyarakat tanpa adanya pengingkaran dari mereka. Bahkan justru individu-individu yang menyelisihi adat tersebut akan dianggap sebagai orang asing. Oleh sebab itu, Islam menjadikan adat komunitas masyarakat sebagai landasan hukum selama memenuhi persyaratan-persyaratan yang ditetapkan oleh syariat. Tulisan ini bertujuan untuk mengkaji kaidah fiqhiyah "al-'âdat muhakkamah" secara umum serta implementasinya dalam bidang keluarga Islam. Jenis penelitian ini adalah kualitatif yang bertumpu pada analisis data yang diperoleh dari literatur-literatur klasik dan kontemporer. Hasil penelitian
\end{abstract}


mengemukakan bahwa al-'adah merupakan sesuatu yang terjadi secara berulang-ulang yang diterima oleh akal sehat dan fitrah manusia. Teori juga dapat menjadi hakim atau penentu hukum selama tidak bertentangan dengan syariat atau tidak keluar dari jalur maqosid syariah. Kaidah al-'Adah muhakkamah juga dapat di implementasikan sebagai hakim dalam bidang hukum keluarga Islam baik klasik maupun kontemporer.

Kata Kunci: Al-'adah Muhakkamah, Teori Adat, Kaidah Fiqhiyah, Hukum Keluarga Islam

\section{A. Pendahuluan}

Islam adalah agama rahmatan lil álamin. Yakni senantiasa membawa kasih sayang dan kedamaian bagi alam semesta serta kebaikan kehidupan manusia. Syariat Islam yang dalam konteks ini adalah maqosid syariah merupakan tuntunan yang Allah turunkan kepada manusia dengan tujuan kemaslahatan sekaligus solusi bagi berbagai problematika hidup yang dialami oleh umat manusia di dunia ini.

Syariat Islam adalah suatu jalan yang harus dilalui ${ }^{1}$, yang menghimpun berbagai aturan-aturan hidup, yang Allah wahyukan kepada manusia melalui nabi-Nya untuk dijadikan sebagai pijakan utama dalam kehidupan mereka selama di dunia. Namun dalam perjalanannya bahwa hukum-hukum yang terdapat dalam Al-Qur'an dan Hadis sifatnya global tidak terperinci. Terkait ini ada ulama yang mengatakan bahwa:

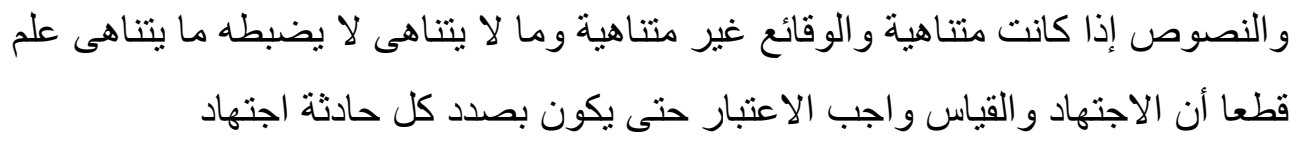

Artinya:

"Jika teks-teks dalil nash adalah bersifat terbatas, sedangkan problematika peristiwa kehidupan senantiasa tidak terbatas, dan yang terbatas tidak bisa menampung yang tidak terbatas, maka disimpulkan

${ }^{1}$ Ria Wati Rahmi, Zulfikar Muhamad "Ilmu Hukum Islam” (Lampung: Gunung Pesagi, 2017), 1. 
secara pasti bahwa ijtihad, berfikir analogis dan rasional adalah sebuah keniscayaan yang sulit dihindari". ${ }^{2}$

Memang pada dasarnya para ulama fiqh atau ushul fiqh berbeda pendapat dalam hal metodologi menggali hukum Islam dari sumbernya. ${ }^{3}$ Misalnya; Imam $\mathrm{Abu}$ hanifah dalam metodologinya menggunakan Ra'yu atau Qiyas, istihsan, 'urf (adat kebiasaan setempat). Namun imam Syafi'i, imam Ahmad, imam Malik berbeda dari Abu Hanifah. Bahkan imam Syafi'i sendiri menolak tegas konsep istihsan sebagai pedoman argumentasi hukum Islam. Perbedaan di antara ulama tersebut hal yang biasa dan lumrah, sebab perbedaan memang dilatar-belakangi dari berbagai faktor diantanya faktor metodologi dalam berijtihad, lingkungan, sosial dan budaya setempat.

Merupakan sebuah realita yang tidak bisa dipungkiri bahwa setiap komunitas masyarakat pasti memiliki tradisi atau adat/'urf yang mereka warisi seacara turun temurun. Dan tradisi ini kemungkinan sama atau mirip dengan tradisi yang ada di sebuah komunitas masyarakat lain. Islam sebagai agama yang memiliki sifat relevan untuk setiap kondisi ruang dan waktu, tentu memiliki sebuah solusi untuk setiap adat yang ada pada setiap komunitas 4 .

Yang menjadi pertanyaan adalah bagaimana implementasi teori al'Âdah dari kaidah fiqhiyah dalam hukum keluarga? Apakah semua hukum Islam bisa dengan leluasa untuk menerapkan kaidah al-'̂Adah Muhakkamah dalam menyimpulkan ijtihad hukum? Oleh karena itu, tulisan ini mencoba mengkaji teori tentang kaidah al-'adah muhakkamah, definisinya, serta pengaplikasian dan implementasinya pada masalah hukum Keluarga Islam.

2 Al-Syahrastani Abu al-Fath Muhammad bin Abdul Karim, al-Milal wa al-Nihal, (Beirut: Dar el-Ma'rifah, 1404 H), j. 1, 197.

3 Tim kurikulum Universitas Imam Muhammad bin Saud, "pengantar fiqih islam", (Riyad: universitas imam muham bin saud).

${ }^{4}$ Kholid Saifullah "Aplikasi Kaidah Al-'adah Muhakkamah Dalam Kasus Penetapan Jumlah Dan Jenis Mahar" AL-MAJALIS: Jurnal Dirasat Islamiyah, Volume 8, No. 1, November 2020 


\section{B. Pembahasan}

\section{Penjelasan tentang kaidah al-'Adah Muhakkamah}

Dalam kaidah fiqhiyah yang pokok disebutkan:

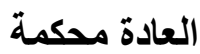

Artinya:

"Kearifan lokal atau adat dapat menjadi patokan atau acuan hukum"5

Secara etimologi, Al-'adah secara bahasa akar kata dari 'ada-ya'udu wa huwa al'aud yang berarti kebiasaan terhadap sesuatu dan terus menerus dilakukan sehingga menjadi karakteristik ${ }^{6}$.

Dalam kamus lisan arabi disebutkan bahwa "ad-daidan" dan "ad-dábu" berarti karakteristik dan kebiasaan yang dilakukan secara kontinu, dinamakan demikian karena pelakunya membiasakan hal tersebut. dalam kamus mufrodat Ar-raghib Al-asfahani disebutkan arti "al-áud" yaitu, kembali terhadap sesuatu setelah berpaling darinya baik sebelum nya berpaling karena dzat, perkataan, dan keingin ${ }^{7}$. Sebagai mana Allah berfirman dalam surat $\mathrm{Al}$-mukminun ayat 107 dan surat $\mathrm{Al}$-an'am ayat 28:

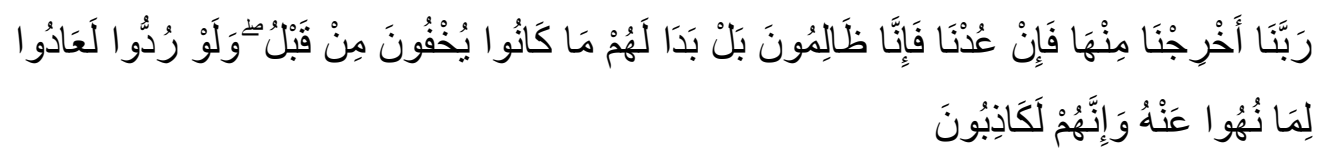

Urf secara bahasa berarti ungkapan yang lembut dan simpel, dalam kamus mu'jam ibnu Faris 'Urf terdiri dari kata $A$ 'in $R a^{\prime} F a^{\prime}$ yang berarti ketenangan, dinamakan demikian karena jiwa-jiwa tenang terhadapnya, Al quran dan sunnah menyebutkan kata 'Urf dalam penggunaannya memiliki

${ }^{5}$ Jalaluddin al-Suyuthy, al-Asybâh wa al-Nadzâir, (Kairo-Mesir: Dar el-Salam, 2009), j. $1,221$.

6 Ad-dausari Muslim Bin Muhamad Bin Majid, Al-mumti' Fii Al-qowaid Fiqhiyah, (Riyad: Dar-zidni 1424H), 269.

7 Sholih Bin Ghonim Sadlan "Al-qowaid Fiqhiyah Al-kubro Wa Ma Taffara'a 'Anha" ......., 331. 
makna setiap sesuatu hal kebaikan dikalangan manusia yang tidak seorangpun yang mengingkarinya dan menganggap buruk ${ }^{8}$.

Dalam tafsir 'Allamah Abi Su'ud disebutkan:

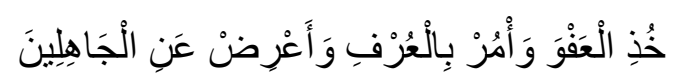

Artinya:

"Jadilah engkau pemaaf dan suruhlah orang mengerjakan yang ma'ruf, serta berpalinglah dari pada orang-orang yang bodoh"

Al-jassos memaknai "ma'ruf" sesuatu yang baik sesuai akal dan diterima oleh orang yang memiliki akal sehat. Sehingga pakar bahasa menyebutkan makna 'adah dan 'urf memiliki makna yang sama/mirip, hanya saja memiliki perbedaan sedikit saja yaitu al-'adah syaratnya berulang-ulang secara tempo, adapun 'urf dilakukan secara kontinu, al-'adah bisa saja menjadi 'urf setelah dilakukan secara kontinu tanpa adanya jeda tempo waktu 9 .

Pengarang kitab al-munir az-zahir fi ushul mendefinisikan al-'adah sebagai sebuah ungkapan atau sesuatu yang terulang dan tertanam pada jiwa-jiwa yang memiliki tabiat dan watak yang sehat. Imam Qarrofi mendefiniskan al-'adah sebagai sebuah kekuatan nilai atau kerifan lokal yang ada pada nilai-nilai masyarakat di semua negara atau sebagianya. Ibnu Amir Al-hajj mendefinisikan sebagai sesuatu yang terjadi secara berulang-ulang tanpa adanya sebab yang bisa dinalar. Definisi Amir Bad Syah, sesuatu yang terjadi secara berulang ulang walau dengan adanya sebab yang bisa dinalar.

Dalam literasi klasik para fuqaha' menjelaskan tentang definisi adat, diantaranya sebagai berikut:

$$
\text { العادة ما تعار فه الناس فأصبح مألوفا لهم سائغا في مجرى حياتهم }
$$

\footnotetext{
8 Sholih Bin Ghonim Sadlan "Al-qowaid Fiqhiyah Al-kubro Wa Ma Taffara'a 'Anha".........., 331-332.

9 Sholih Bin Ghonim Sadlan "Al-qowaid Fiqhiyah Al-kubro Wa Ma Taffara'a 'Anha"..........., 332-333.
} 
Artinya:

"Adat adalah segala apa yang telah dikenal manusia, kemudian hal itu menjadi kebiasaan yang berlaku dalam kehidupan mereka baik berupa perkataan atau perbuatan". ${ }^{10}$

Dalam ini juga juga disebutkan terkait definisi 'urf:

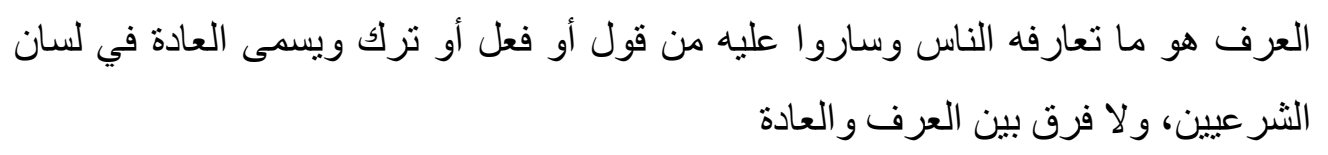

Artinya:

"Urf adalah apa yang dikenal oleh manusia dan berlaku padanya, baik berupa perkataan, perbuatan atau meninggalkan sesuatu. Dan ini juga dinamakan adat di kalangan ulama syariat. Tidak ada perbedaan antara urf dan adat"11

Dari definisi di atas dipahami bahwa tidak adaperbedaan definisi antara 'adah dan 'urf'12 bahkan tidak ada pertentangan dari definis-definisi tersebut, ${ }^{13}$ namun pada definisi Ibnu Amir Al hajj dan Amir Bad Syah adanya perbedaan yaitu terletak pada sebabnya, kalau definisi Ibnu amir Al haj mensyaratkan tidak adanya sebab yang bisa dinalar, sedangkan definisi Amir Bad Syah tidak mensyaratkan hal tersebut. Sehingga setiap kejadian yang terjadi secara berulang-ulang bisa dikatakan sebagai 'adah menurut definisi Amir Bad Syah, sedangkan menurut Ibnu Amir Al hajj tidak dikatakan 'adah, kecuali jika sebab terjadinya secara berulang ulang adalah sebab yang tidak bisa dinalar. Sebagai contoh: Haid adalah 'adah bagi wanita baik menurut definisi no 3 dan no 4, karena sebab haid adalah sesuatu yang tidak bisa

10 Asjmuni Abdurrahman, Qawa'id Fiqhiyah; Arti, Sejarah dan Beberapa Qa'idah Kulliyah, (Yogyakarta: Suara Muhammadiyah: 2015), 54.

11 Ibid., 54.

12 Sholih Bin Ghonim Sadlan "Al-qowaid Fiqhiyah Al-kubro Wa Ma Taffara'a 'Anha' ............, 334.

13 Kholid Saifullah “Aplikasi Kaidah Al-'adah Muhakkamah Dalam Kasus Penetapan Jumlah Dan Jenis Mahar".........., 66-67. 
dinalar. Contoh lain: makan ketika lapar adalah 'adah menurut definisi no 4, dan bukan termasuk 'adah menurut definisi ke tiga.

Makna 'urf secara istilahi Hafid An-nasafi mendefinisikan 'adah wa 'urf adalah sesuatu yang bisa diterima oleh akal sehat dan fitrah manusia. ${ }^{14}$ Adapun kata "muhakkamah" isim maf'ul (bentuk objek) dari kata hakkamayuhakkimu yang berarti menjadikan hakim. Sehingga makna kalimat "al'adah muhakkamah adalah adat atau tradisi yang dijadikan landasan hukum.

Dari definisi di atas, dapat disimpulkan bahwa definisi kaidah "al'adah muhakkamah" adalah sesuatu yang terjadi secara berulang-ulang yang bisa diterima oleh akal sehat dan fitrah manusia yang dijadikan sebagai acuan hokum. ${ }^{15}$ Setidaknya terdapat dua unsur yakni:

(1) Al-'Adah yang dilakukan secara berulang-ulang, sebuah kebiasaan yang dilakukan hanya sekali, dua kali bukan termasuk 'adah dalam konteks kaidah diatas.

(2) Al-'Adah yang diterima oleh akal sehat dan fitrah manusia, tentu tidak keluar dari tujuan syariat, kebiasaan diluar hal tersebut tidak dapat dijadikan acuan hukum, semacam kebiasaan mencuri, berbohong praktek-praktek ibadah di luar jalur konteks maqosid syariah.

Bila dicermati dari penjelasan diatas, dapat dipahami bahwa ${ }^{16}$ al-adah dan 'urf merupakan dua istilah yang sama maknanya, meskipun menurut beberapa ulama ada yang menganggap terdapat perbedaan dalam penggunaannya. Memang benar bahwa para ulama berselisih pendapat mengenai apakah adat sama dengan 'urf, namun secara global tidak ada perbedaan pokok yang mencolok antara adat dan 'urf. Al-Adat sendiri dimaknai sebagai kebiasaan secara umum tanpa melihat apakah dilakukan satu orang atau kelompok. Sedangkan 'urf bermakna sebagai kebiasaan yang

14 Sholih Bin Ghonim Sadlan "Al-qowaid Fiqhiyah Al-kubro Wa Ma Taffara'a 'Anha" 335.

15 Kholid Saifullah "Aplikasi Kaidah Al-'adah Muhakkamah Dalam Kasus Penetapan Jumlah Dan Jenis Mahar"... 68.

${ }^{16}$ Faiz Zainudin “Konsep Islam Tentang Adat: Telaah Adat Dan 'Urf Sebagai Sumber Hukum Islam” Jurnal: Lisan Al Hal, Volume 9, No. 2, Desember 2015 
dilakukan banyak orang/kelompok dan timbul dari kreatifitas atau imajinatif dalam membangun nilai-nilai budaya.

\section{Syarat-syarat pengaplikasian "Al-'Adah Muhakkamah"}

Kaidah diatas sangat universal, artinya dapat masuk pada semua bab fiqih khususnya dalam muamalah. Namun tidaklah semua kearifan lokal yang dapat diakui berdasarkan kaidah diatas, namun ada syarat-syarat yang memang harus terpenuhi agar 'adah tersebut shohih sesuai kaidah diatas, diantaranya: ${ }^{17}$

Tidak bertentangan dengan dalil-dalil syar'i yang lebih kuat, karena bila 'adah bertentangan dengan nash yang lebih kuat, maka yang menjadi acuan utama hukum nash. Sebagai contoh: tradisi masyarkat jawa dahulu bila beretemu pejabat/raja maka menghormatinya dengan sujud maka nash $\mathrm{Al}$ quran melarangnya, sujud hanya pada Tuhan yang maha esa. Contoh lain: tradisi riba dan nash $\mathrm{Al}$ quran mengharamkannya.

'Adah tersebut lebih sering dilakukan dari pada ditinggalkan, dan pelaku 'adah mayoritas masyarakat bukan minoritas, karena bila 'adah lebih sering ditinggalkan dan pelakunya minoritas maka tidak dapat menjadi patokan hukum.

Kesesuaian sikap dan lafaz bagi pelaku 'adah, jadi pelaku 'adah tidak menafikan tradisi yang ia lakukan, bila antara pelaku 'adah dan tradisi berseberangan apa yang ia ucapkan maka yang menjadi acauan hukum adalah ucapanya bukan 'adahnya. Contoh: seorang penjual memiliki kebiasaan dalam transaksinya bahwa ongkir ditanggung penjual, suatu ketika ada problematika antara penjual dan pembeli, dan penjual mengatakan bahwa ongkir ditanggung pembeli, maka disini 'adah bukan menjadi acuan hukum melainkan ucapan penjual yang menjadi patokan hukum.

17 Sholih Bin Ghonim Sadlan "Al-qowaid Fiqhiyah Al-kubro Wa Ma Taffara'a 'Anha” pada bab (syarat-syarat pengaplikasian kaidah al-'adah muhakkamah). Lihat pula jurnal Kholid Saifullah "Aplikasi Kaidah Al-'adah Muhakkamah Dalam Kasus Penetapan Jumlah Dan Jenis Mahar" pada bab (syarat pengaplikasian kaidah al-'adah muhakkamah). 
'Adah sudah ada ketika terjadinya akad, karena tidak bisa dijadikan acuan hukum 'adah yang tidak ada ketika terjadinya akad.

Sebagai contoh: dahulu tradisi mahar menikah adalah sepeangkat alat sholat, dan dimaknai mukena saja. Lalu muncul tradisi baru bahwa yang dimaksud seperangkat alat sholat adalah mukena, sajadah, tasbih. Maka suami yang menikah dengan tradisi lama (hanya mukena saja), maka tidak membayar sebagaimana tradisi baru, karena tradisi terjadinya akad waktu dulu sebagai acauan hukum.

\section{Kedudukan kaidah}

Bahwa kaidah diatas adalah termasuk kategori yang sangat agung, karena memiliki pengaruh yang sangat luas sebagai dalil fiqih khususnya terkait dengan ke arifan lokal. Dan yang paling agung adalah bahwa kaidah ini dapat menyingkap hukum sesuai situasi dan kondisi budaya masyarakat, selama budaya tersebut tidak keluar dari maqosid syariah.

Teori adat juga menawarkan solusi hukum Islam yang elastis dan relevan disetiap zaman, maka disebutkan dalam kaidah turunannya:

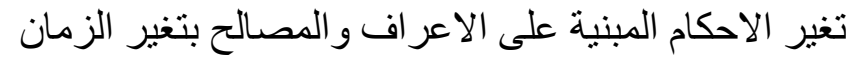

Artinya:

"Perubahan hukum yang didasarkan pada teori adat dan mashlahat itu disebabkan karena berubahnya zaman".

Kemudian dari kaidah al-'Adah Muhakkamah ini, muncul kaidahkaidah cabang yang lebih memperjelas kaidah besar di atas, diantaranya adalah sebagai berikut:

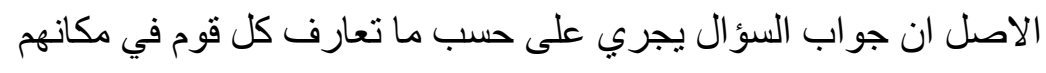

Artinya: 
"Hal pokok yang harus digunakan adalah bahwa jawaban atas pertanyaan itu harus berlaku sesuai adat suatu kaum pada wilayahnya masing-masing."18

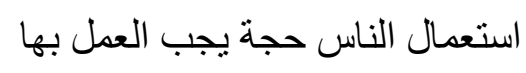

Artinya:

"Kebiasaan yang dilakukan masyarakat adalah hujjah yang harus diambil sebagai landasan argumentasi" ${ }^{19}$

Contoh: apabila seseorang meminta tolong kepada kawannya untuk membelikan sebuah ladang/sawah, setelah terjadinya transaksi lalu ia meminta upah, maka ukuran besaran upah kembali kepada kebiasaan masyarakat sekitar.

$$
\text { تعتبر العادة اذا اطردت او غلبت }
$$

Artinya:

"Kategori 'adah adalah apabila hal tersebut sering dilakukan atau mayoritas (masyarakat) melakukanya. contoh dari kaidah ini sama seperti contoh kaidah berikutnya".20

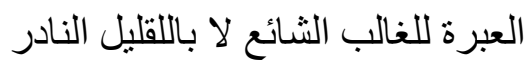

Artinya:

"Yang menjadi patokan atau acuan dalam hukum adalah yang mayoritas tersebar di masyarakat bukan yang minoritas (jarang dilakukan oleh masyarakat)".21

18 Ad-dausari Muslim Bin Muhamad Bin Majid, Al-mumti' Fii Al-qowaid Fiqhiyah, (Riyad: Dar-zidni 1424H), 268-269.

19 Ad-dausari Muslim Bin Muhamad Bin Majid, Al-mumti' Fii Al-qowaid Fiqhiyah, (Riyad: Dar-zidni 1424H), 285.

20 Ad-dausari Muslim Bin Muhamad Bin Majid, Al-mumti' Fii Al-qowaid Fiqhiyah, (Riyad: Dar-zidni 1424H), 295.

21 Ad-dausari Muslim Bin Muhamad Bin Majid, Al-mumti' Fii Al-qowaid Fiqhiyah, (Riyad: Dar-zidni 1424H), 299. 
Contoh: kapan dinyatakan nya sebagai harta warisan dan dibagi kepada ahli waris ketika orang yang hilang/mafqud (pergi tidak kembali)? Yaitu ketika sudah melewati usia 90 tahun, dikarenakan mustahil usia manusia melebihi 90 tahun, ada namun jarang. Contoh lain: sahnya membayar sewa/upah jasa mengajarkan Al quran/imam sholat/adzan supaya sebagai motivasi dirinya dan orang lain, ada yang mau menunaikan hal tersebut secara sukarela, namun jarang/sangat sedikit. Contoh lain: usia baligh sebagaimana dinyatakan fuqoha untuk laki-laki 15 tahun, untuk perempuan 9 tahun. Hal tersebut sesuai adat kebiasaan bila sudah melampau usia tersebut maka sudah baligh, bila ada yang melebihi hal tersebut maka jarang.

$$
\text { لاينكر تغير الاحكام بتغير الازمنة و الامكنة والاحوال }
$$

Artinya:

"Suatu hal yang maklum (tidak diingkari) perubahan hukum sesuai/relevan dengan perubahan ruang dan waktu serta kondisi".22

Contoh: dimasa rosulullah wanita diperbolehkan berjamaah dimasjid, namun ketika dizaman abu bakar dilarang karena kondisi tertentu. Contoh lain: diperbolehkannya mengunci pintu masjid pada waktu tertentu karena perubahan kondisi kotoran, kemalingan maka diperbolehkanya mengunci pintu masjid. Contoh lain: menurut madhab hanafiyah dan hanabilah dilarang seseorang yang terlilit hutang untuk melakukan transaksi apapun baik hibah, wakaf, dan amalan tabaru' lain karena perubahan kondisi yaitu orang suka lalai untuk membayar hutangnya atau dengan bahasa lain menagih hutang lebih malu dari pada mau mencari hutangan, sehingga orang tersebut dilarang untuk melakukan transaksi shodaqoh. Contoh lain: dulu menikah hanya cukup dengan ijab qobul, adapu sekarang karena sesuai kondisi masyarakta maka pelu adanya pencatatan di KUA.

$$
\text { المعروف عرفا كالمشروط شرطا }
$$

22 Ad-dausari Muslim Bin Muhamad Bin Majid, Al-mumti' Fii Al-qowaid Fiqhiyah, (Riyad: Dar-zidni 1424H), 313. 
Artinya:

"Urf atau tradisi (masyarakat) menjadi acuan hukum hal tersebut bagaikan sebuah kesepakatan yang nyata". 23

Contoh: seseorang menyewa rumah dan belum terjadi kesepakatan harga dan mereka saling percaya, maka yang menjadi acuan hukum (upah sewa) yaitu kembali pada umumnya tradisi masyarkat tersebut. contoh lain: seseorang menyewa kendaraan pribadi maka untuk hal tersebut mengangkut hal-hal yang memang mengangkut barang yang lumrah sesuai tradisi masyarakat, bila mengangkut hal-hal berat maka sesuai tradisi penyewa yang nanggung. Contoh lain: bila seseorang menyewa mobil truck maka kapasitas angkut barang harus sesuai tidak boleh melebihi kwantitas angku pada truck tersebut. contoh lain: bila seseorang berkunjung kerumah temanya sesuai tradisi ia boleh makan minum apa yang ada didepannya meski tanpa se izin pemilik rumah, atau ia memecahkan gelas ketika minum maka ia tidak wajib mengganti.

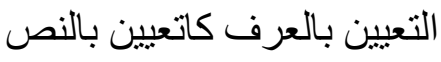

Artinya:

"Ketetapan berdasarkan 'urf itu bagaikan ketetapan berdasarkan dalil syar'i atau nash". ${ }^{24}$

Contoh: bila ada seseorang menyewa toko dipasar kain, maka penyewa tidak dipekenankan menggunakanya untuk las besi atau kuliner sate (bakar-bakaran) yang dapat menggangu tangga lainya, hal tersebut tidak sesuai tradisi pada area tersebut.

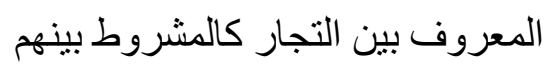

Artinya:

${ }^{23}$ Jalaluddin al-Suyuthy, al-Asybâh wa al-Nadzâir, (Kairo-Mesir: Dar el-Salam, 2009), j. 1, 192.

24 Sholih Bin Ghonim Sadlan "Al-qowaid Fiqhiyah Al-kubro Wa Ma Taffara'a 'Anha” (Riyad: Dar-balnasiah 1417H), 328. 
"Suatu (tradisi) menjadi acuan hukum antar pedagang hal itu bagaikan kesepakatan-kesepakatn antar mereka".25

Contoh: bila ada seorang membeli barang dagangan dari luar daerah dan belum ada kesepakatan tentang upah ongkir, maka yang menjadi acuan hukum adalah tradisi ongkir dari satu daerah kedaerah lain, hal tersebut bagaikan kesepakatan antar pembeli dan penjual. Contoh lain adalah wesel.

\section{Landasan dalil kaidah "al-'adah muhakkamah"}

Kaidah "al-'adah muhakkamah" disepakati oleh para ulama,yang menjadi sandaran dalil dari kaidah tersebut diantaranya: firman Allah:

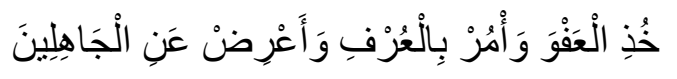

Artinya:

"Jadilah engkau pemaaf dan suruh lah orang mengerjakan yang ma'ruf, serta berpalinglah dari orang-orang yang bodoh"26

Imam Suyuti menafsirkan 'urf diatas sesuai dengan kebiasaan baik masyarakat sekitar ${ }^{27}$.

Firman Allah diayat lain:

$$
\text { و على المولود له رزقهن وكسوتهن بالمعروف }
$$

Artinya:

"Dan kewajiban suami memberi nafkah kepada istri dan anaknya dengan cara yang ma'ruf'. ${ }^{28}$

Dalam hadits juga disebutkan :

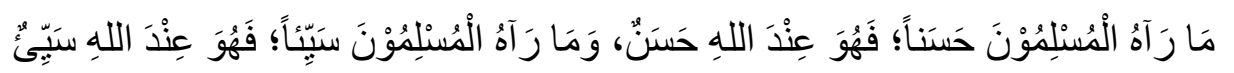
Artinya:

25 Ad-dausari Muslim Bin Muhamad Bin Majid, Al-mumti' Fii Al-qowaid Fiqhiyah, (Riyad: Dar-zidni 1424H), 310.

${ }^{26} \mathrm{Al}$ 'araf ayat 199

27 Sholih Bin Ghonim Sadlan "Al-qowaid Fiqhiyah Al-kubro Wa Ma Taffara'a 'Anha'......., 338.

${ }^{28} \mathrm{Al}$ baqoroh ayat 233 
"Apa saja yang dipandang kaum muslimin merupakan kebaikan maka ia di sisi Allah juga merupakan kebaikan. Dan apa saja yang dipandang kaum muslimin merupakan keburukan maka ia di sisi Allah juga merupakan keburukan". 29

Kesimpulan makna yang tersurat dalam ayat diatas bahwa dengan cara ma'ruf yakni ukuran nafaqoh diberikan kepada istri dan anaknya sesuai adat masyarakat sekita ${ }^{30}$.

Hadits nabi yang diriwiyatkan oleh Hindun Binti Utbah, Nabi bersabda:

$$
\text { خذي ما يكفيك وولدك بالمعروف }
$$

Artinya:

“Ambilah dari harta suamimu sesuatu yang mencukupimu dan anakmu dengan cara yang ma'ruf'

Artinya Nabi memerintahkan hindun untuk mengambil harta suami sesuai dengan takaran adat nafaqah masyarakat sekitar ${ }^{31}$.

\section{Beberapa contoh penerapan kaidah al-'adatu muhakkamah pada kasus bidang Hukum Keluarga}

Penerapan kaidah al-'adah muhakkamah dapat terlihat pada beberapa contoh $^{32}$ dalam hukum keluarga Islam sebagai berikut: Nafkah dalam keluarga ukuran standardnya berdasarkan kebutuhan yang berlaku sesuai adat pada wilayah tertentu. Sebagaimana disebutkan dalam al-Qur'an:

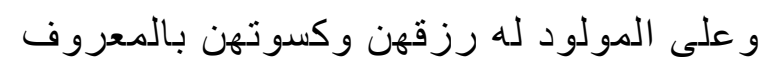

Artinya: j. $1,221$.

${ }^{29}$ Jalaluddin al-Suyuthy, al-Asybâh wa al-Nadzâir, (Kairo-Mesir: Dar el-Salam, 2009),

30 Muslim Bin Muhamad Bin Majid Ad-dausari "Al-mumti' Fii Al-qowaid Fiqhiyah" '......, 272-273.

${ }^{31}$ Muslim Bin Muhamad Bin Majid Ad-dausari "Al-mumti' Fii Al-qowaid Fiqhiyah"......., 27.

32 Muhamad Az-zuhaili "Al-qowaid Fiqhiyah Wa Tatbiiqotuha Fii Al-madzhaib Arba'ah" (Dar Al-fikr:Damaskus 2006). hlm. 302-306. Dan Sholih Bin Ghonim Sadlan "Alqowaid Fiqhiyah Al-kubro Wa Ma Taffara'a 'Anha"......., 376-381. 
“Wajib bagi ayah (kepala rumah tangga) untuk memberikan nafkah dan pakaian kepada istri mereka sesuai kebutuhan yang lumrah dan berlaku di daerahnya."33

Ditambah dengan sebuah hadits yang shahih Riwayat bukhari muslim:

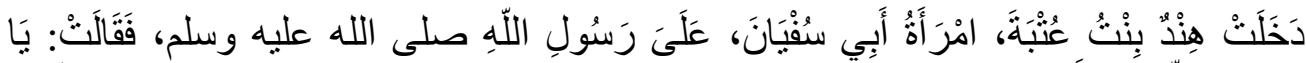

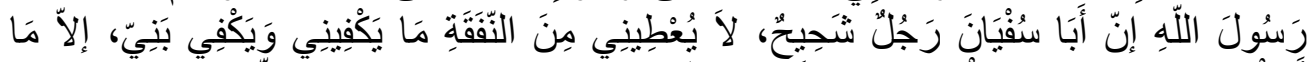

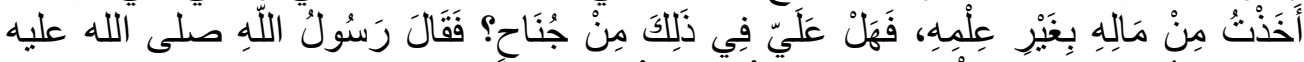

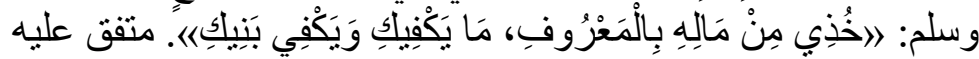

Artinya:

"Hindun Binti 'Utbah, isteri Abu Sufyan berkunjung untuk bertemu Rasulullah kemudian berkata, 'Wahai Rasulullah, sesungguhnya Abu Sufyan adalah orang yang sangat kikir, enggan memberikan nafkah kepadaku dengan nafkah yang mencukupi untukku dan anakku kecuali dari apa yang aku ambil dari hartanya tanpa sepengetahuannya. Apakah aku berdosa karena hal itu.?' Rasulullah SAW menjawab, 'Ambillah dari hartanya yang cukup untukmu dan anakmu sesuai adat kebutuhan yang berlaku."34

1. Apabila seorang suami berkata kepada istrinya: "diantara kebiasaanku adalah bahwa jika aku berkata kepadamu: 'engkau terceraikan', maka yang aku maksudkan adalah agar engkau berdiri dan duduk, bukan bermaksud cerai." Dari ucapannya tersebut, jika suatu saat suaminya mengucapkan "engkau terceraikan" maka tidak bisa dihukumi sebagai hukum talak atau cerai. $^{35}$

2. Ukuran kaffarat terhadap pelanggaran berhubungan suami-istri di siang bulan Ramadhan adalah memberi makan kepada orang miskin seukuran standard bahan makanan di wilayah setempat. ${ }^{36}$ Di dalam al-Qur'an disebutkan:

${ }^{33}$ Q.S. al-Baqarah: 233

${ }^{34}$ Imam Bukhari, Shahih al-Bukhari, j. 2, hlm. 769, dan Imam Muslim, Shahih Muslim, j. 3, 1338.

35 Al-Dausary Muslim, al-Mumti' Fî al-Qawâ'id al-Fiqhiyyah, (Riyad: Dar Zidni 2007), 281. 273.

${ }^{36}$ Al-Dausary Muslim, al-Mumti' Fî al-Qawâ'id al-Fiqhiyyah, (Riyad: Dar Zidni 2007), 


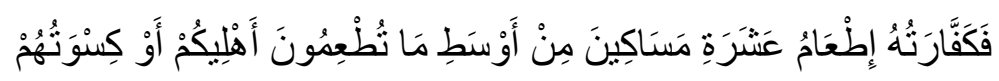

Artinya:

Maka kaffaratnya ialah memberi makan sepuluh orang miskin, yaitu dari makanan yang biasa kamu berikan kepada keluargamu, atau memberi pakaian kepada mereka. ${ }^{37}$

1. Dalam hal wasiat, apabila ada orang arab mengatakan:

$$
\text { أوصيت للقر اء }
$$

Artinya:

"Aku memberikan wasiat kepada al-Qurra".

Secara Bahasa, diksi al-Qurra' mencakup siapapun yang membaca alQur'an baik dengan melihat secara langsung ke mushaf atau melalui hafalan. Namun adat arab merubah makna ini, sehingga diksi al-Qurra' hanya terkhusus bagi mereka yang menghafal al-Qur'an atau hafidz. ${ }^{38}$

2. Diantara masalah fiqh yang hukumnya ditetapkan berdasarkan teori adat adalah terkait akad pinjam meminjam buah yang sudah menjadi kebiasaan di masyarakat Madinah. ${ }^{39}$ Sebagaimana yang diterangkan dalam hadits:

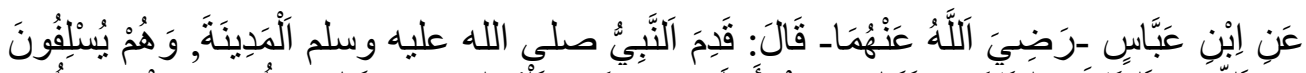

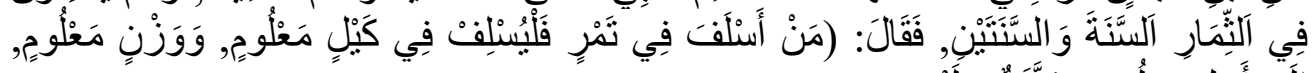

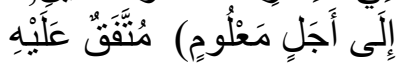

Artinya:

Nabi Shallallaahu 'alaihi wa Sallam datang ke Madinah dan penduduknya biasa meminjamkan buahnya untuk masa setahun dan dua tahun. Lalu beliau bersabda: "Barangsiapa meminjamkan buah maka hendaknya ia meminjamkannya dalam takaran, timbangan, dan masa tertentu." 40

37 Q.S. al-Maidah: 89

${ }^{38}$ Al-Dausary Muslim, al-Mumti' Fî al-Qawâ'id al-Fiqhiyyah, (Riyad: Dar Zidni 2007), 280.

39 Asjmuni Abdurrahman, Qawa'id Fiqhiyah; Arti, Sejarah dan Beberapa Qa'idah Kulliyah, (Yogyakarta: Suara Muhammadiyah: 2015), 55.

40 H.R. Bukhari dan Muslim 


\section{Penutup}

Kaidah Fiqhiyah al-'̂̂dah Muhakkamah atau yang biasa disebut dengan teori Adat adalah merupakan kaidah sangat penting dalam memahami hukum Islam. Terlebih teori adat ini digolongkan oleh para ulama fiqh ke dalam kategori kaidah besar yang memiliki sub cabang kaidah fiqhiyah di dalam. Hal ini tentu menjadi sangat penting untuk dijadikan sebagai pedoman pertimbangan dalam menetapkan hukum Islam oleh para mujtahid di setiap zaman, terkhusus pada era saat ini dalam menjawab tantangan problematika hukum yang senantiasa berkembangan mengikuti arus globalisasi dan modernisasi.

Dalam implementasinya, teori adat atau kaidah al'Âdah Muhakkamah memiliki syarat dan aturan tertentu yang harus dipenuhi, di antaranya yang paling penting adalah tidak adanya nash dalil yang qoth'I atau dzonny yang memenuhi syarat argumentasi sebagai dalil, dan harus tidak bertentangan secara substansinya dengan kaidah fiqh lain yang lebih tinggi kedudukannya.

Implementasi teori adat dalam hukum keluarga Islam juga sangat penting digunakan, terlebih dalam beberapa masalah yang tidak ditemukan solusinya dalam literatur klasik para fuqoha'. Di antara contoh implementasi kaidah al-Âdah muhakkamah dalam hukum keluarga Islam adalah terkait ukuran nafkah yang wajib diberikan oleh suami kepada istri dan anakanaknya, juga terkait redaksi talak yang tidak dimaksudkan untuk menceraikan istrinya, dan termasuk ukuran kaffarat yang wajib ditunaikan ketika melanggar beberapa ketentuan hukum Islam, baik yang bersifat mahdhah maupun ghairu mahdhah. 


\section{DAFTAR PUSTAKA}

Abu al-Fath Muhammad bin Abdul Karim, Al-Syahrastani, al-Milal wa alNihal, Beirut: Dar el-Ma'rifah, $1404 \mathrm{H}$

Abdurrahman, Asjmuni, Qawa'id Fiqhiyah; Arti, Sejarah dan Beberapa Qa'idah Kulliyah, Yogyakarta: Suara Muhammadiyah: 2015

Al-Suyuthy, Jalaluddin, al-Asybâh wa al-Nadzâir, Kairo-Mesir: Dar el-Salam, 2009

Az-zuhaili, Muhamad, Al-qowaid Fiqhiyah Wa Tatbiiqotuha Fii Al-madzhaib Arba'ah, (Dar Al-fikr:Damaskus 2006).

Ghonim Sadlan, Sholih Bin, Al-qowaid Fiqhiyah Al-kubro Wa Ma Taffara'a 'Anha, Riyad: Dar-balnasiah 1417H.

Kementerian Agama, al-Qur'an dan Terjemahnya, Jakarta: Kementerian Agama RI, 2018

Muslim, Al-Dausary, al-Mumti' Fî al-Qawâ'id al-Fiqhiyyah, Riyad: Dar Zidni 2007

Nasrullah, Hukum Adat Dan Penerapannya Dalam Ekonomi Islam, Jurnal, Volume 2, Edisi 2, Juli 2013.

Rahmi, Ria Wati, Muhamad, Zulfikar, Ilmu Hukum Islam, (Lampung: Gunung Pesagi, 2017).

Saifullah, Kholid, Aplikasi Kaidah Al-'adah Muhakkamah Dalam Kasus Penetapan Jumlah Dan Jenis Mahar, AL-MAJALIS: Jurnal Dirasat Islamiyah, Volume 8, No. 1, November 2020.

Tim kurikulum Universitas Imam Muhammad bin Saud, Pengantar fiqih islam, (Riyad: universitas imam muham bin saud

Zainudin, Faiz, Konsep Islam Tentang Adat: Telaah Adat Dan 'Urf Sebagai Sumber Hukum Islam, Jurnal: Lisan Al Hal, Volume 9, No. 2, Desember 2015. 